\title{
The last lieder of Theodor Grigoriu. Stylistic and interpretive aspects
}

\author{
CEZARA PETRESCU \\ "George Enescu” National University of Arts Iasi \\ ROMANIA*
}

\begin{abstract}
Theodor Grigoriu, a reference figure for the $\mathrm{XX}^{\text {th }}$ century Romanian music, as a senior of the post-enescian generation of composers, with a moderately modern attitude towards composing, had explored the expresive resources of the human voice in the vocal-symphonic and vocal-chamber genres. Although, from a quantitative point of view, his voice and piano works are not too numerous and the vocal-chamber genre had not been a constant focus of the composer, lied remains one of the most representative areas of his entire creation, marked by an accomplished literary taste and harmoniously neighboured by the halo of poetry. The lied had marked Theodor Grigoriu's professional existence, beginning with the first childhood experiments which proved decisive for his future career, up to the inconstant achievements of his creative maturity. Although approached in a non-consistent manner, the diversity, mastery of composition and the abutment to works from a more ample genre to which he resonates and configures genuine "creation laboratories", the voice and piano cycles of works represent what can truthfully be called lied creation. Letter to birds on words by St. Francisc of Assisi (2004) and The iconographer - The poem of a church painter (2011) on words of a patriarchal, novel text with no poetic aspirations, are the last lieder of Theodor Grigoriu, published posthumously. As a binding of music and poetry into a one poethico-musical universe, they are an exponent of accumulations and transformations of musical language, spectacular compositions, of paramount originality, which harmoniously complete the spiraled path of the genre in the context of the composer's entire creation.
\end{abstract}

Keywords: Theodor Grigoriu, romanian music, lied, stylistic aspects.

\section{Introduction}

Theodor Grigoriu, "a great artist and thinker of our days" (Constantinescu, 2013, p. 391), "a representative artistic personality for the contemporary Romanian music” (Cosma, 2000, p. 246), a reference figure of the $\mathrm{XX}^{\text {th }}$ Romanian music, had explored the expresive resources of the human voice in the vocal-symphonic and vocal-chamber genres. The lied had marked his professional existence, beginning with the first childhood experiments, which proved decisive for his future career, up to the inconstant achievements of his creative maturity. Although approached in a non-consistent manner, the

\footnotetext{
* cezpetrescu@yahoo.com
} 
diversity, mastery of composition and the abutment to works from a more ample genre to which he resonates and configures genuine „creation laboratories" the voice and piano cycles of works represent what we will prove that can be truthfully called lied creation.

His last two lieder are novel topic of research. Like the other 42 lieder signed by Theodor Grigoriu, they are not a priority of the current theoretical interest, the preference of those who analyse, discuss, investigate the works of the Master sporadically focusing more on his works of ampler genres.

In the last two decades, the knowledge of individual contributions to the history of Romanian music has become more difficult, due to drastic reduction of the area of expression in spectacle-centered institutions and a limited circulation of study materials. The exegesis of Theodor Grigoriu's creation, tackled either fragmentary or as a whole, is limited from a quantitative point of view, being represented by lexicographic articles, essays dedicated to Romanian music and scientific works, with the great monography still missing. Precious information exists in greeting articles, concert cronics and, not least, ample doctoral works where Romanian vocal-chamber compositions are tackled sequentially.

Wanting, through the means of this research, to cover a part of the present void of knowledge and to emphasize significant stylistic elements for future interpretative investigations, I made use of accessible resources, updating the existent data that I had, which, with the passing of the Master, have found a deffinitive form.

Along with other own contributions to the knowledge of Theodor Grigoriu's lied creation - special CD recordings, recitals, Lieder on haiku and tanka words in Romanian creation (2007, volume I), the Sonorous Hypostases for a Tanka Poem study (2009) in Bulletin of the Transilvania University of Braşov, expositions in various scientific contexts - through the found conclusions, this study aims to be part of a new stage of knowledge and enhancement of contemporary Romanian lied, especially with regard to the Master's lieder.

Throughout this study, I am mostly addressing to possible interprets of vocal-chamber compositions, be them singers or pianists, pointing them out a series of elements that I consider necessary for a knowledge-based interpretative investigation, which will lead them to the accomplishment of a genuine interpretation. As such, by no means of a grid, but by adapting everything to the target goal and by pointing out the main elements, I provide the core information that, infused by particular stylistic aspects, leads to the founding of a consistent core. This, alongside the sensitive sound cloud generated by the listening of a composer's music, determines a positive evolution of instinct (Johnson, 2004, in: Parsons, editor, p. 320) and a state of artistic mastery in which "the conscious and the subconscious, the rational and intuitive sides become one” (Baremboim, 2015, p. 69). 


\section{Aspects regarding the creation of a word-fascinated post-enescian senior}

Inspired by "his models of beauty, the classical art, the monasteries of northern Moldova and the grandious harmony of the space where he saw the light of day" (Grigoriu, 2006, $2^{\text {nd }}$ cover), the composer, Theodor Grigoriu (1926-2014), proudly self-situated himself inside the Romanian componistic phenomena which, in the early 80', he considered 'constituted, through an active dynamic of ideas from all generations, [...] homogenous, through the high value of the ideas that it contains and debates, [...] solid, in a sense that it shows a logically coherent reasoning which is not lost into details, [...] lucid, through the preciseness of observation done more relevantly on a universal scale, [...] permeable to all that is valuable and able to operate genuine syntheses” (Grigoriu, 1986, p. 147).

A senior of the post-enescian generation of composers, with a moderately modern attitude towards composing, as noted by the musicologist Valentina SanduDediu (2002, p. 68) the Master was sure of the value of tradition, which he praised as a very precious "dowry, a memorial of our victories in the realm of the sensible" (Marinescu, 2016, p. 110) and treated it with reverence, in a contemporarious renaissance style, without carrying it as a burden of standardised ambitions. He identified himself with and embraced the Romanian melos, but "had always tuned it to the world's music diapason" (Manolache, 2002, p. 53), moving intensively, like Enescu did, consistently following his componistic calling, that of "a genuine modern following of Enescu's principles of creation, and also the one of capturing the ethos of modal music" (Sandu-Dediu, 2002, p. 241).

Without turning his creation into a "shooting range of experiments" (Grigoriu, 2006, p. 99), he developed innovative solutions and ideas of maximum originality, which he considered "necessary in the process of creation, in order to reach a certain expression, asked by institutions and imagination” (Grigoriu, 2006, p. 99): the componistic process, the (re)return to the idea of ethos through the summoning of imaginary folklor and its investigation, the pioneering in the use of etherophonia, the invention of the wavy series, the use of formal tier-based dispositions, the exploitation of surprise and weary ideas in music, "the recall of neums (Grigoriu, 2006, p. 104), the sinthesys between the sound beam and the psaltic accompaniment, the use of truncated scores, the first achievement of a tape-music in Romania (1962), the patenting of the idea of a counterpoint between music and image in film music, the invention of the musical topo-semiology method and, not least, the approach on violin in a genuine manner, still unique at the present time ${ }^{1}$.

Theodor Grigoriu composed works of various genres, especially for monumental genres, tackled with the equilibrium of an architect who he wasn't

\footnotetext{
${ }^{1}$ For detalis, check Theodor Grigoriu, Internet, 2006, pp. 99-111.
} 
meant to be, with the rigor of the mathematician he could had become and with the famous mastery of instrumental and voccal-instrumental ensemble's sound. He rethought the internal influences that derive from the pupil-master relationship and from the admiration towards the great spirits of mankind, keeping them at reverent distance and realizing a genuine sinthesys with elements that lasted and evolved in time in spiral, generating factors that individualize its cultural physiognomy.

For this study, I mention the usual possibilities of mapping for a composer's creation - the usual staging of creation from a chronological perspective, the ordering of works depending on their membership to a specific musical genre and the ordering in correlation to the preffered sound material and I reiterate the opinion of Grigore Constantinescu, musicologist, friend and fine expert of Theodor Grigoriu's creation, who proposes a possible classification of his works depending on "some inspiring enumerations" which he considers, citing the composer's opinion, "indicators [...] leading in the artistic process [...] pairs of intuition-reaction”: The Byzantium, Ovidius, Orpheus, Divinity, waters, space, Antiquity (Constantinescu, Theodor Grigoriu - The master has left us, 2014).

With the aim of refining the classifications, I bring to attention a different perspective, starting with an affirmation of the composer, apparently voided of signifficance, casually stated, as a matter-of-course fact: "the mission of man on Earth is to grow in spirit" ${ }^{2}$ He understood the means of achieving this through music and words (Grigoriu, 1986, p. 281), means precious to him through which he generously yielded time and music. All of his works can be considered reverences, (towards universal culture personalities, towards musicians who decisively influenced him, towards the performers who he admired and, not least, towards Divinity), impressions (due to various places, situations etc.) or offerings (unselfish gifts from others' music, returned to contemporaneousness).

The reverence, be it also musical, a condescendent salute of supreme elegance, seems to me as a natural attitude for a noble, subtle and refined musician, who „cultivated that elevated saloon behaviour in all aspects of life (Bura in: Marinescu, 2016, p. 96). The research can detect the variety of reverences amongst Theodor Grigoriu's works and the surprisingly large number of compositions that can be included under this generous curtain.

The category of works which I consider impressions resides under the effect of some of the composer's affirmations who, in a mix of modesty and playfulness, explained himself in front of his readers or co-speakers. Inspired by Messiaen, the Master simply admitted the existence of the profoundly-

2 Transcript from the interview granted to Eugenia Vodă for “The Professionals”, National Romanian Television (TVR) 
subjective substrate of his works and the variety of experiences that he caused (Grigoriu, 2006, $2^{\text {nd }}$ cover), oftenly admitting that, being motivated by state of being determined by an image in a certain moment, he has a personallyverified recipe, freeing himself of an idea by writing it ${ }^{3}$.

Theodor Grigoriu's offerings are unselfish gifts of other's music. Especially in the last decades of his life, the Master, seeking to preserve to posterity old foundation stones, reiterates models for the anchoring in safe componistic principles, with a high degree of force, opposed to some postmodern impulses which are yet to confirm their perenniality. Being interested in the "paths in time of some masterpieces" (Constantinescu, ,Viaţa de creaţie", continuitate în timp a destinului artistului dispărut - compozitorul Theodor Grigoriu [The creation life, continuity in time of the disappeared artist's destiny - Theodor Grigoriu the composer]), offered a new sound to some works, for an easier circulation on concert life. Admiring his Renaissance-type cultural profile, I noticed that the Master has returned to his public, not only music, but also fascinating literary pages, unique, which became vocal-chamber or vocal-symphonic compositions. Throug the aforementioned works, the Master Theodor Grigoriu discretely and consistently places himself in service of music, loyal to his convictions: "to not especially put yourself in the light is the fate of music, but to reflect it around, through the gift and power of the spirit, warming the hearts and the imagination” (Marinescu, 2016, p. 121).

Theodor Grigoriu had a special relationship, privileged and assumed with literature, placing his work in the vicinity of the poetic halo ${ }^{4}$. Olga Grigorescu, musicologist, noted that "the word-music duality accompanied him his whole existence, argumenting not only through her large number of conclusions, studies, articles about the artistic phenomenon and about great musicians which she celebrated, but also through the solicitude with which he presented each creation, demonstrating the exact same thing, the availability to use the apparently more accessible literary language, alongside the more difficult to translate sound language, [...] with great talent, with a special gift of words, phrases, figures of style, image associations' expressiveness" (Grigorescu, in Marinescu, 2016, p. 92). The mottos, the subtitles attributed to compositions or parts of the compositions, the dedications and auto-presentations are, on the one side, guidelines for interpreters and public for the understanding of poethico-musical meanings and metaphors, and on the other side, are charming literary pages written with talent and love for verb and sound.

\footnotetext{
${ }^{3}$ From the talks with the Master Theodor Grigoriu.

${ }^{4}$ Muzica şi nimbul poeziei, ediţia I [Music and the halo of poetry, $1^{\text {st }}$ edition] is the title of the collection of essays (1986).
} 
Anyone who covers Master Grigoriu's list of creations can observe a defining aspect, his fine literary taste. The preference towards quality texts can be seen in works for voice and piano (Dinu Athanasiu, Ion Zăgan, Veronica Porumbescu, Mihai Eminescu, Lucian Blaga, Ion Barbu, Tudor Arghezi, Şerban Codrin, St. Francisc of Assisi, text from the XIX ${ }^{\text {th }}$ century), in stage music (Cehov, Molière, Sofocle, Shakespeare, Edmond Rostand, Eugène Labiche, Mihail Sadoveanu, Büchner, Arthur Miller, Ben Jonson), in vocal-symphonic music (Nina Cassian, Ovidiu, Dante, Shelley, Puşkin, Eminescu, Rimbaud, Rilke, Lorca, Iulia Haşdeu, biblical texts) and, not least, in film music. The depth of knowledge and understanding of the fusion between word and sound in universal music - a problem perennially approached by philosophers, ethnographs, historians, musicians, estethicians, as Theodor Grigoriu noted (1979) - fundaments and legitimizes the composer's exceptional achievements in genres that call for the involvement of literature.

\section{Theodor Grigoriu's lied creation}

It may seem self-understood that the pretentious lied genre, which incorporates music and poetry into a sensible, organic and quasiindestructible phrasing, to take be of such importance in the creation of a musician "seduced by a text [...] because he hears a possible music stirring inside him” (Grigoriu, 1986, p. 167), fascinated by the poethico-musical metaphor, by the possible, laborious and inspired binding between music and word for the achievement of a pluridimensional reception environment. Noting Theodor Grigoriu's ópus-es, the density of his piano and voice compositions, throughout the span of his variously themed creation, is more pronounced in his last two decades of activity, the lied being neighbored by works of ampler genres, with which he constitutes "creation laboratories" 5 . These areas of interest are detectable from an initial analysis through the communicating vessels represented by the musical material used and through the technical manner of his approach. Inside the seeming musical maze, as more profound research is completed, more subtle paths and connections are revealed, based on influences, resonances, impressions.

I use the phrase creation of lied regarding the Master's 44 lieder, in the spirit of the necessary clarification suggested by the musicians who, hovering over the line of a more refined musicological analysis, take into consideration the usage of adequate terminology: creation of lied or collection of lieder (Sandu-Dediu \& Dediu, 2013, pp. 161-162). The main arguments for are:

\footnotetext{
${ }^{5}$ That phrase belongs to the Master Theodor Grigoriu.
} 
- The songs belong to different creation periods, the spacing marking specifically the stylistic changes and the belonging to the sound sinthesys that took place in the composer's melting pot, in his journey to universality ${ }^{6}$;

There's a strong anchoring in the philosophical and musical dominant ideas of the creating moment when they appear;

The songs for voice and piano are representative for the entire creation, configuring a defined compartment, periodically updated, and defining, being, as the Master described it, "sound documents of thought and sensitivity of a certain moment in time"7;

- $\quad$ The grouping into cycles, from and editing and naming point of view (an exception being Three sheperd songs, Under the birch and the last two compositions, Letter to the birds and The Iconographer - The poem of a church painter);

- In the process of naming, the composer uses, either the name of song, assumed via Jora, or the one of poem, which establishes the symbiosis between text and music, or suggestive titles, infused with poetry - a "dreamed, far away and boundless" (Grigoriu, 1986, p. 7) space, with great power of suggestion, leading to "a certain universe if ideas and feelings" (Grigoriu, 1986, p. 185);

- Lieder are representative for a certain corpus of works of his creation (the use of wavy series, the reference to God) and for a part of his this genre of compositions in Romanian music (religious lied, lieder on lines of haiku and tanka);

For each cycle, there is unity regarding the sound imagery, composition technique (a modal, serial, tonal enlarged sound material; the technical means of approach), the text-music relationship, formal structure, type of voice (song parameters) and the relation with the instrumental match (be it simultaneous or successive), the type of piano writing (accompaniment formulas, preferences regarding harmonic and/or polyphonic approach), unity in terms of expression (various poethic sources, sometimes unitary, but always aiming for a one idea, central theme, a coherent message) and structure (there is a quasidramaturgical idea in the organization of cycles, an intersection of keywords and poethical-musical images).

Theodor Grigoriu's contact with lied was early, atypical and determining for his musical and professional future. From the dialogues with the Master and subsequent readings, I found out that, as a student in primary school, in a childish spirit of competition, he declared that he can write a song. And he did so, the teacher praising him and singing along with the children his first try of writing music on poetry. The composer confessed after decades: "the

\footnotetext{
${ }^{6}$ For terminological clarifications, check Octavian Nemescu, The semantic capacities of music, Muzicală Publishing House, Bucharest, 1983, p. 152.

${ }^{7}$ Free quotation, from the talks with the Master Theodor Grigoriu.
} 
multiplying of my own thought with fifty voices seemed to me a miracle. Probably that was the moment when the idea of being a composer felt so clear to me" (Manolache, 2002, p. 54).

The first lieder, Three sheperd songs (1950), appeared from the desire of linking his creation to the Romanian geographical space - which he began to know directly through his trips around country in the company of his good friend, the poet Dinu Athanasiu (Ion Zăgan), author of the lieder's lines - and under the strong impression that the phenomenon of transhumance made on him. Theodor Grigoriu confessed that he was inspired by this phenomenon, by the sheperds' state of being in different situations - Towards the valley, To wintering and On the hill - discovering the Romanian sound and scenery, in a juvenile "thirst for space". The Master, at old age, interpreted this thirst for space as "a thirst for knowledge, in fact, a redescovery of some data that you have inside yourself" (Manolache, 2002, p. 57) marked by formative aspirations, by the wish of identification with a popular creator, of aligning to the time mainstream. The creation phase inaugurated by the Aromanian (Macedonian-Romanian) sound inflections from his Sheperd songs continues the investigation of man's relation with space and time, up to the point of using imaginary folklor. In the same "creation laboratory" I place Under the birch lied (1952) for voice and piano, on words by Ion Zăgan, unpublished.

Autumn songs - Five poems on words by Veronica Porumbacu (19521962) is a "composition began and continued on autumn-come [...] the state of being that inspired him" (Grigoriu, 2006, p. 23): the musical melancholy of a good friend's lyrics and the ineffable of a Romanian autumn. The five pieces for voice and piano - The falling asleep of colors, The wind, The smile of light, The Rain and October - use a post-enescian musical technique, based on a free chromatism. The sound profiles attributed to voice arch especially from small intervals, and the instrumental score realizes a comment, not an accompaniment, with the aim of prolonging the poethic methaphor (Grigoriu, 2006, p. 23 and Grigoriu, 1986, p. 406), with the aim of creating, inspired by his knowledge of film music, a pluridimensional space of reception. Poethic stimulus generate sound interesting sound solutions, which bring unity of atmosphere, a distinctive mark of expresiveness produced by the suggestive sound equivalences for the poethic imagery and by semantic charges highlighted surprisingly. The visual dimension involved represents the common ground of the lieder, and the perception and just interpretative realization of colors are the challenges raised to imagination and affective memory of the interprets.

Autumn songs, through their succesive rethinking, neighbor very different compositions, which, successively or simultaneously embracing neoclassical impulses, liberties of modern techniques, the reporting to folklor and the restless exploitation of ethos, reveal the experiments and decantations of 
Theodor Grigoriu with the aim of stylistic crystalization. Although published during lifetime of the Master and collected in the Radio Sound Archive, through reference interpretations of the 1960s, Autumn songs are unknown to contemporary public, awaiting a well-deserved revisiting by young musicians.

After the achievement of the orchestral great refinement version of Seven songs on lyrics by Clément Marot by George Enescu (1964) ${ }^{8}$, Theodor Grigoriu left early the lied genre, dedicating himself to more ample genres.

The comeback to the more subtle, difficult and sophisticated lied genre occurs in 1993, with the Poets and the abyss of time cycle. Uniquely for his lied creation, Theodor Grigoriu chooses lyrics belonging to several poets (Mihai Eminescu, Lucian Blaga, Ion Barbu, Tudor Arghezi), aiming "to highlight the obsessive idea of the time in Romanian poethic art" (Grigoriu, 2006, p. 29) and to individualize through music "the genuine poethic tone" (Grigoriu, 2006, p. 29) of Romanian culture. Believing that time is insensitive to a certain ethos, the Master approaches the wavy series, of which mathematical configuration underlines the main idea of the composition, the irreversibility of time. Through the use of this technique, the cycle of lieder borders with Cosmic dream and with the vocal-instrumental symphony The sea's vocalizations, the rigor of serial approach being less strict and the sound dimension having offering a certain degree of liberty, in relation to the poethic text.

The six lieder of the cycle - To the star-Prologue, Road to abyss, The moment of Genesis, Nighted morning, Flight above the waves and To the starEpilogue - form a quasi-symmetric structure which highlights the inspiring ideas of the poethico-musical composition: musical time, existential time, cosmic time and the "instantaneous and long-lasting" effect of methaphor time over men's sensitivity (Grigoriu, 2006, p. 29). Most interesting is the placing of To the star as, bot, a prologue and an epilogue of the lied cycle, the last appearance suffering, as the composer noted, "the erosion of time, even though between the two apparitions only few minutes have passed" (Grigoriu, 2006, p. 29). The aim of piano accompaniment is decisive in the accomplishment of erosion, through the rhytmic and sound register diversification, in the context of an identical voice line in both lieder. From a formal structure point of view, each lied takes into consideration the poethic structure, its architecture being the result of a novel interpretation of the poethico-musical metaphor.

Poets and the abyss of time lieder cycle is a suprising stage in Theodor Grigoriu's creation, through the use of wavy series and the omission (just for the moment!) of ethos. Although the sound is novel, the moment of audition

\footnotetext{
${ }^{8}$ For the autopresentations realized by the composer Theodor Grigoriu, check the volumes The music and the halo of poetry, 1986, pp. 426-430 and Internet, 2006.
} 
reveals a series of now-characteristic elements of the composer: the complex elegance, without the aim of it at all costs, the absence of flashy sound densities, despite the occasional coarse and tensed surfaces, the vocal and piano surprising colors, and, nevertheless, the role of piano in the ensemble economy.

The instrumental score exceeds in complexit the traditional pattern of a piano accompaniament for the lied genre, noticeable being the fusion between the vocal dimension and the instrumental one. The decisive role of piano in the sound mechanism is given by the generous ambitus (sometimes the piano writing is noted on three staves), from which the variety and timbre expressiveness, the rich color scheme, the expressive force. The difficult for the pianist is the obtaining of the composer imagined sound, through the diversification of means of approach (type of sound articulatio corelated to the dinamic, large, rigorous outline noted in the score and the poethico-musical expression of the composition as a whole) and a permanent placing - from a sound-expressive point of view - inside the complex organism of a vocalchamber duo.

The piano and voice lieder cycles on lyrics by Şerban Codrin which make up The haikai collection are essences of an extensive and complex experience achieved by an aphoristic densely expressive manner of approach. The resulting chamber trilogy seems an auto-reflexive creating process, an investigation of own Ego, an oscillation between conflict and harmony, between discontinuity and continuity.

9 Haikai - Beyond silence, Jesus meant a new shifting point in Theodor Grigoriu's creation, essentializing elements from previous works which highlight Byzantine music tier, neighboring most profoundly the Byzantium after Byzantium ("Trinity" concert; "In the great passing" sonata; "The eternal return" sonata) cycle and initiating the report to Divinity (Aeterna Verba in anno MM; 33 Psalms; A liturgical symphony; Letter to birds; The Iconographer) under the influence of some perennial metaphors in his creation: time, space, surrounding nature.

11 Haikai-Beyond silence, the spirit of the plain fall into the theme of space inevitably intersecting the meditation regarding time, with the impressions caused by the extent of Bărăgan plains. The lieder cycle takes the aspect of an ideatic synthesis and is strongly connected to previous works by means of the thoughts and ideas that inspired it: Romanian space (Three sheperd songs; Symphonic variations on a song by Anton Pann; The four seasons) which "arrive somewhere" (Grigoriu, 2006, p. 65) and are invoked through a modal sound primordiality), the cosmos (Cosmic dream), the vast plains (The sea's vocalizations), time (Romanian seasons in which we highlight the sound clock marking the passing of time), the ethos of Romanian Music (The modal column in which, for their acoustic role, cvart, quint and 
octave intervals are being introduced); Symphonic variations on a song by Anton Pann in which miniature themes invoke, alongside others, city folklor, sound world at the intersection of the Orient and Occident; Pastorals and transylvan love songsin which the imaginary character observes the ambience of the world he lives in (Grigoriu, 2006, p. 54), the miracle of miniature world, of the small creatures (Bucolic virgilian polyphony).

7 haikai - Beyond silence, journey with birds is a possible reply to Messiaen's Catalogue of birds, conceived in relation to Romanian geographic space and with reports to universal symbolism of world of the winged. The preffered sound language places lieder in the continuation of the Master's specific means arsenal, accumulated in time, molded on Japanese sensitivity, on aphoristic previous cultural models and corelated to contemporary man's pragmatism.

The projected Comedia mundana cycle remained unfinished, Theodor Grigoriu finalizing Letter to birds on lyrics by St. Francisc of Assisi (2004) and sketching, without finalizing, The wise man of whom no one has need on lyrics by Nichita Stănescu, for that time grew impacient with him.

\section{Scrisoare către păsări a Sfântului Francisc din Assisi [Letter to the Birds of Saint Franscisc of Assisi]}

The lied for voice and piano Scrisoare către păsări a Sfântului Francisc din Assisi [Letter to the Birds of Saint Franscisc of Assisi] (2004) enrolls in the works which allude to belief without urging and to Christianity without invoking. It ss a creation of full creative maturity which, according to some possible tracing of Theodor Grigoriu's works propposed by the musicologist Grigore Constantinescu, finds itself under the influence of divinity, as an indicator which determines what the Master called "pairs of intuition-reaction" in the artistic process (Constantinescu, 2014, Theodor Grigoriu - The Master left us).

According to the proposals of mapping the before mentioned creation, the lied Scrisoare către păsări a Sfântului Francisc din Assisi Letter to the Birds of Saint Franscisc of Assisi [Scrisoare către păsări a Sfântului Francisc din Assisi] has triple grouping. On one side, it belongs to the group of pious reverences of maturity of a tentative composer who rather prized the sovereign creator principle, which he preferred considering, for now, arcane to the inhabitants of Terra. The vocal-chamber works - the cycle Dincolo de tăcere, Iisus [Beyond the silence, Jesus] (1999), Scrisoare către păsări and IconarulPoemul unui zugrav de biserici [The Iconographer - The poem of a church painter] (2011) - gravitate around the works of a monumental aspect, composed in the last years of life and creation of the Master, as it follows: $O$ simfonie liturgică [A liturgical symphony] $(2000,2002)$ for choir and orchestra based on religious texts, dedicated to "those who do not believe", has a strong 
autobiographic character, being "written under the influence of a certain space and time. As space, Romania in the last decades of the $20^{\text {th }}$ century, notorious worldwide as one of the most self-distructive country, and as time the approach and passing of the year 2000, an astral privilege granted to those who lived this moment” (Grigoriu, 2006, p. 87). Aeterna verba in anno MM (2000) for mixed choir, awarded right in the year of its composition by The European Institute of Choral Music and Loren Fillarmonic (Metz) is covered in the symphony as a last bit which can be sang separately. The 33 Psalms (1989-1998) for mixed choirs on biblical texts, with a superb motto - "At the end of the road on Earth/ we reached the edge of eternal solace of God./ On the road we picked some flower./These psalms He dictated to us.” (Grigoriu, 2006, p. 90) - evoking the lifetime of Jesus among men, it declares itself a "stilistic union" (Grigoriu, 2006, p. 90) with the Romanian choral creation which the Master notably cherished. Theodor Grigoriu loved the interprets with whom he collaborated, he had a unique communication with each individual, devoting to them, with generosity and appraisal, the interpreted works. The lied is dedicated to the mezzosoprano Mihaela Agachi, the one who interpreted it at the first audition not long before she'd prematurely reach the end of her journey in this world.

On the other hand, I consider the lied Scrisoare către păsări a Sfântului Francisc din Assisi belongs to both the category of impressions and to the category of offerings, because the Master was surprised by the beauty and novelty of the text, but even more so by the play of chance which made it so that the words of St. Francissc landed in his hand, being provoked to compose, to renew to the public a peculiar text, adorning it with surprising sound.

Profusely impressed by the situation created and convinced that the nature of the notes coming from the composer are always meant to clarify and direct the thoughts and emotions of the interprets, the composer notes in his score: "This text of a great beauty was communicated to me by my friend, the writer Constantin T,oiu who, at Paris, copied it from the noticeboard of Church Saint Germain Prés. Following the next day to check if his transcription was corect, the text was already gone. Asking a cleric where it had gone, the later stated that those texts are changed daily, each saint being mentioned on the day dedicated to him, once a year. Let us thank God and Saint Francisc of Assisi for this encounter with a light of poetic divinity" (Grigoriu, 2016, p. 9).

Composed in the near adjacent temporality as the cycle Dincolo de tăcere, drum cu păsări [Beyond silence, a way with birds] the lied comes to complete the catalogue of the winged in a componistic manner far away from the webernian aphorism of the haikai cycles, yet sublty touched by some profound elements of the oiseaux style and the admiration of the Master for Messiaen's preocupation for birds and for St. Francisc of Assisi (Grigoriu, 1989, p. 22). 
Ever since the glossing over the score, it surprises the entwining between vocally and instrumentally, the complementarity of the two discourse type, the equilibrium, the floating aspect proposed by the melodic linse through sense, the registry and type of articulation and not lastly the richness of indications regarding the expression which models the discourse and guides the interprets without equivoque.

The formal structure dictated by the literary text ${ }^{9}$ is asymmetrical, consecvently following the unity of the poetico-musical metaphor in which the word and the sound fraternize and unravel a visible componistic action of small measure specifically done to showcase the value of word and the melodic context in which those multiply their senses.

The thoroughgoing study of the reading unravels o modal-diatonic melodic world, in which the mobility of musical intervals create a subtle major-minor play, the ajoutée elements beieng used in moments of utmost tension, for instance, in instrumental chord structures (quasi campane) which, at the climax of the whole unfolding towards the end, before a codetta of 8 measures (meno mosso, senza rigore), which touch the orchestral complexity.

The cantabile melody emmanates simplicity without being facile, contouring a descriptive atmosphere, evocative, calm, through the invoking of gregorian melody and Byzantine melodicity (expressive force of concealed accompaniament in accord structures). The equilibrium between the ascending and descending directivity, between the slow buildup and small jumps in intervals, alternated qualitatively, generates, alongside suggestive rhythmics, a wavy mobility that follows the inflections in day by day speech and suggests flight. The expressive resources of primary intervals, of the formatively modal and of the seventh, interval with a heavy modal load resulting from the succesion of fourths, are explored by Theodor Grigoriu in his own unmistakable style. I remark the vertical and horizontal projection of the fifth (perfect or reduced, filled or not with thirds) and to highlight the value of the same type of resonance through the unraveling of the small seventh.

The melodic segments of the vocal score are suitibly articulated to the size of a verse spoken in a single breath, the rhythm following the melodic reflex of the text in a perfect synchronization with the expression. In combination with the gradual buildup, small intervals are preferable, usually up to a fifth, alternatting their quality and their ascendant or descendat sense on a melodic line, in corelation with the poetic text. The overlapping between the

\footnotetext{
9 "Birds, sisters of mine,/ God helps you,/ For you do not sow, nor do you sickle./ He gives you:/ springs and rivers,/ so you can drink from them when thirsty;/ hills and mountains/ and tall trees, so you can make nests there./ And because you don't know how to spin or to sew ,/ He gives you:/ warm and colourful clothes/ for you and your babies./ The Creator loves you a lot/ if he makes you so many gifts./ And for that, my dear sisters,/ celebrate and praise/ Our Lord.”
} 
vocal melodic line and the instrumental score is ingeniuous, the technical and expressive complexity of the accompaniment and the melodic plasticity required for their realisation requiring a rich imagination and superior levels of technical means. I mention in the same vein the segment Con moto, leggiero (mm. 27-33) in which on narration is bestowed a voice, commented giocoso by the piano, through alternative jumps of third over eight and fifth, staccato, in an acute registry, while in the grave registry are succeeded descendent chords of four notes, unfolded sequentially, legato, alternated with small thirds staccato, in a rhythmic configuration that suggessts the flurry of the birds that build their nests.

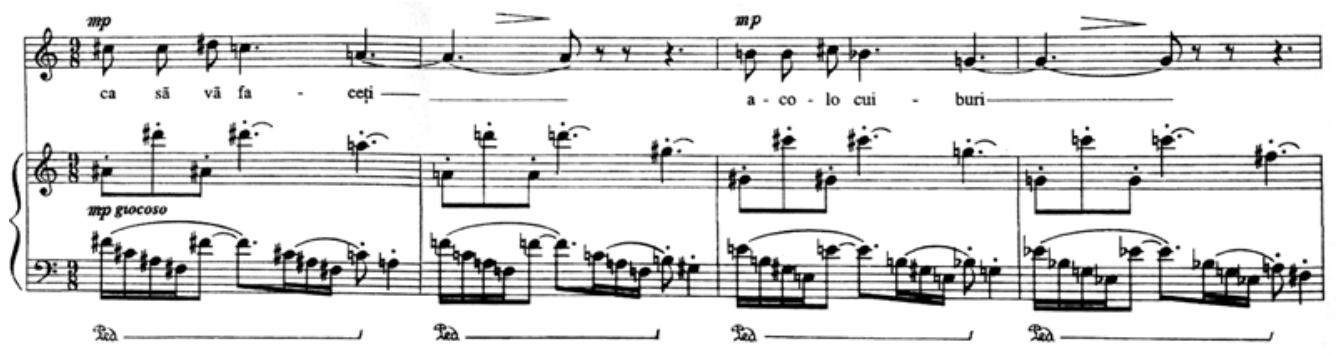

Fig. 1 Theodor Grigoriu, Scrisoare către păsări, mm. 27-30

The intonation types sometimes allude towards the cantabile of the arioso but it constitutes especially in recitative situation: the recto-tono recitative (m. 12 și $\mathrm{m}$. 34, senza rigore, libero) the insinuation of the schönbergian's sprechgesang through ascending intervals solved tardily. The interval used is so adherent to the word, at the inflections of the speech and linguistic expression, that it seems a unique solution to the expression of naturallity and the poetico-musical metaphor.

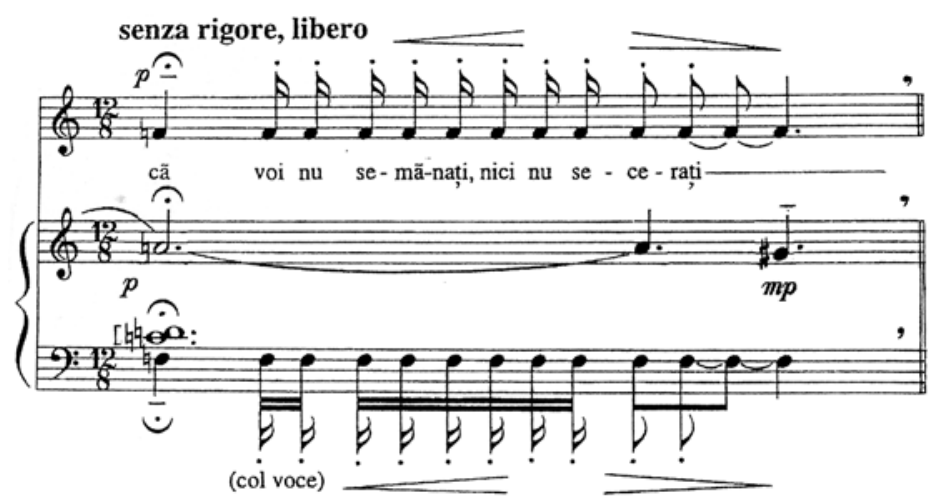

Fig. 2 Theodor Grigoriu, Scrisoare către păsări, m. 12 


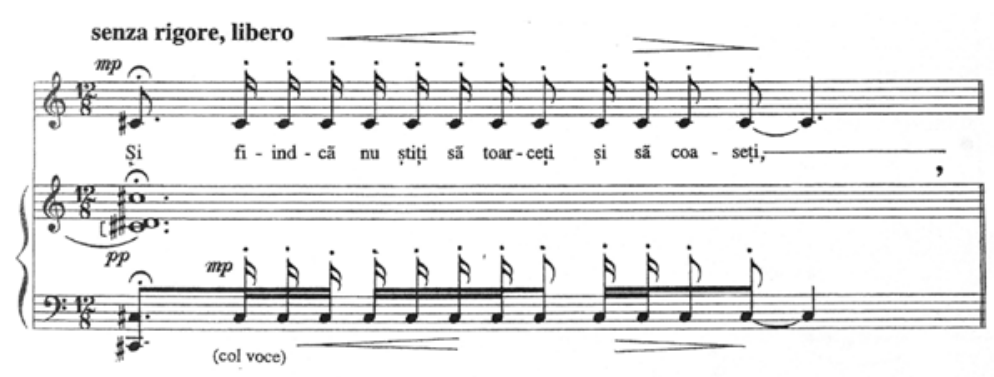

Fig. 3 Theodor Grigoriu, Scrisoare către păsări, m. 34

The rhythm has expressive essence, being an element that strongly highlights the poetic sense, the composer potentiates the semantic value of the words through ingeniously combined rhythmic formula and in corelation with the other parameters of the musical discourse. For example, Theodor Grigoriu prefers the repettion of rhythmic structures or melodico-rhythmics that generate a thematic ostinato, especially on the instrumental score (rhythmic morif in uninterrupted repetition, mm. 15-20, con moto, disinvolto), but also the frequent repeatability of the small third descending third (for example, the word „nest”, in $m p, p, p p$, mm. 29-32).

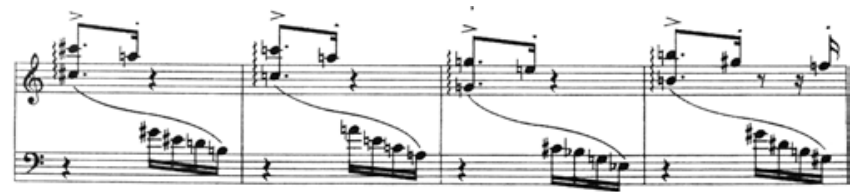

Fig. 4 Theodor Grigoriu, Scrisoare către păsări, mm. 17-20 (piano)

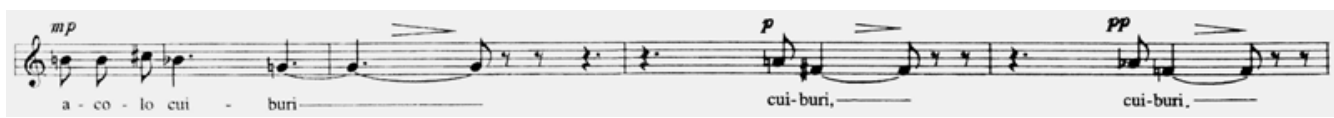

Fig. 5 Th.Grigoriu, Scrisoare către păsări, mm. 29-32 (voice)

I remark a preference for symmetry in the case of rhythmic microstructures, realised through a personal alchemy: in an ingenius way it creates diversity withouth the existance of fragmentation, the repeatability of the formulas and the preference for anacruzal structures are restful, non monotonous

I find it interesting to menion that, although the melodic line is sectioned by pauses, these gestionate exiting the last sound and don't share the purpose of spliting the vocal discourse. Also, often times short values are tied to longer values, which leads to a noted ritartando, on extended durations contoruing a sublte rubato of the melodic discourse. There is an original way of using the 
syncope and contretemps, elements of metronomic conflict, which are detectable especially from a visual perspective (reading the score), but from a melodic standpoint they are melted in the context in which they appear. Thus I do not adhere to the image of a melodic conflict which is detectable especially on a teoretic lever, but ti the waving melody, caressing, floating, endearment, it is about the lag of the voice on a certain syllable, prolongued through the skilled game of rhythmic combinations.

Alternative measures offer elasticity, fluence and an impromptu aspect to the musical discourse due to the fact decisive are the anatomy of the literary text and the succession of accompaniment structures and not the binary or ternary character of the melodic line.

Although from a visual stadpoint, the score is loaded with alterations, the modal harmony is delicately iradiated with chromatisms, mobile intervals and a few ajoutée elements being present. The melodic ambience close to the tonal functionality is made whole by the highlighting of the expressive potential of fifht and eight intervals, alongside thirds and sevenths, intervals remediated and reinvested with reason by Theodor Grigoriu in his last two decades of creation.

A last consideration about the lied Scrisoare către păsări a Sfântului Francisc din Assisi refers to its poetico-musical universe in the two elements seem to hold equal weight. In the moment of audition, of the poetico-musical moment, it encompasses the parallelism, the complementarity and exemplary equilibrium between text and music, the absence of thick brushes in expression and the superb display of the technico-expressive arsenal of the composer.

\section{Iconarul - Poemul unui zugrave de biserici [The Iconographer - The poem of a church painter], coronat opera in a playful note}

The last lied completed by the composer Theodor Grigoriu, before parting beyond silence ${ }^{10}$, is Iconarul - Poemul unui zugrav de biserici [The iconographer - The poem of a church painter] (2011) for voice (bass-baritone) and piano, (based) on an old text with no poetic aspiration published in the supplement Aldine of a daily paper in Bucharest, a surprising and spectacular work.

The text of Iconarul, dating back in the $18^{\text {th }}$ century, was discovered by chance. As the composer notes in the score "in 1831, the painter Marin Todosie restored the painting of St. Mina Church in Craiova. To justify his expenses and due payment, he presents the list of executed works:

1) I've put a new tail to St. Petruși's rooster and I straightened its comb.

2) I tied to the cross the right robber and gave him a new finger.

3) I put a wing on Archangel Gabriel's back.

${ }^{10}$ You will see the titles of the haikai cycles. 
4) I washed Caiaf's maid and put a blush onto her cheek.

5) I renewed the sky, I added two stars and cleaned up the moon.

6) I restored the hellfire red, gave Lucifer a tail and sharpened his claws.

7) I repaird Saint Anton's coat and put two buttons to his gown.

8) For Tobias' son, who rides along Gabriel the angel, I put a new belt to his bag.

9) I washed the ears of Avesalom's donkey and put him horseshoes.

10) I tarred Noe's ark and patched its bilge.

11) I whitened Saint Nichola's beard.

12) I sharpened Saint George's spear and I refreshed the green on the dragon's tail.

13) I washed Saint Maria’s gown.

14) I put a new tail to the devil from Saint Margaret and I patched the semantron" [pseudo-instrument used in the monastery/church to anounce the begginig of the offices, our note] (Grigoriu, 2016)

In the conversations with Master Grigoriu, it always surprised me that, in spite of his senectitude, he had a very youthful way of getting enthusiastic in front of a text which seduced him. His assessment was that, ,the value of a text consists, obviously, of the originality, the beauty and the richness of the meanings of its ideas, and details must be as beautiful and interesting, especially when they become the basis for music.” His accomplished literay taste always led him towards inspired choices resonating with his indwelling disposition and sound workshop in which the inspiration of the moment was leading him.

In this case, "the plasticity and quality of images and metaphors, their elevation and nobility, the fluency of expression, a special sound of words" (Grigoriu, 1986, pp. 167-168) inspired in him a solid, essentialized and fluid work, charming sound alchemy in a ludic key, filtered by the sharp sensitivity of his lyrical nature and deep insight into essences. I do not hesitate to notice that, with thoroughgoing study of the work, a part of the Master's thoughts and composing mechanisms are revealed. Once a text attracted his attention and resonated with his own sensibility, inspired by the ideas, images and metaphors of the verse, the music takes form and substance, the motifs, the harmonies, the timbre colours revealing themselves in a flash. This graceful moment is followed by "a profound reflection over the text, deciphering its deep meanings and correlations, the desire to achieve an ideal musical transposition, [...] tenacious labour and long meditation, carried out on several levels” (Grigoriu, 1986, p. 167).

It resulted in a work that breaks structural originality, with inlfuences taken from previous works of ample genres.The free form "with a rather dramaturgical musical plan" (Grigoriu, 1986, p. 438) makes you think of the string orchestra play Melodie infinită [Infinite Melody], the insinuation of 
sound beams, combined with the Byzantine accompaniment and choral suggestion essentialisedthe fresco idea used in the oratory Canti per Europa, and the stylization of dramaturgical and architectural ideas, through the instrumental lead with a courtain role which, once opened, alows for the scroll of character-ideas, reminds us of Suita teatrală în stil clasic [The theatrical suite in classic style].

Akin to Ofrandă clipelor eterne [Offering to the eternal moments] (2007) for cello and string orchestra, piano and horn, the lied Iconarul... [The iconographer...] has an aspect of musical fantasy. The 14 formal articulations of small dimension which follow the curtain's raising (the pianist lead), possible immanence of the 27 Haikai composed with the sporadic thoughts at Webern and Messiaen, ar the expression of the thoughts and feelings of a unique character, the iconographer, found in contact with the imaginary plane, in which he carries his work as a restorer, and with the concrete plan, in which he is situated as a quantification of his work, for the purpose of payment. As in other works by Theodor Grigoriu, interesting is the dynamic plane, wide, very diverse, and the agogic, scrupulously noted by the composer, efficient the configuration of the poetic-musical metaphor, both firm and delicate guidance of the interprets: 1) Laborioso, con pietà; 2) Grave; 3) Sereno; 4) Con sentimento; 5) Laborioso I; 6) Con fuoco; 7) Calmo, con pietà; 8) Epico, biblico; 9) Laborioso II; 10) Animato; 11) Con pietà; 12) Laborioso, Grave; 13) Soave, dolce; 14) Laborioso III.

The original musical solution of a seemingly trivial theme reveals an energetic spiritual play that leaves the unuttered to unfold, the word to unravel and enrich itself through the mysterious induction of text and visual imagery suggested with humor.

Garnished with perceptible experiences and manifestations, the iconographer's feelings towards the characters within the paintings he is restoring are reflected in an exhibition which borders the folk music's theatricoratorical recitative, spiced up with diffuse suggestions stemming from film music composition technique. The succesion of themes/motifs "after the epic principes of folk narration of the ballad type” (Grigoriu, 1986, p. 77), the perpetual rhythmic variation and richness of timbral colours create a peculiar melodic image of a concentrated and suggestive expression which transcends the possible influences from Jora and Haciaturian. Musical ideas apppear stated with clarity and fidelity for his principle of not creating simultanious sound or expression densities, with an ingenius simplicity which highlights their diversity, cultivating the detail and contrasts in service of the equilibrium of the whole.

The lied Iconarul... [The iconographer...] unravels a profound knowledge of the sublte mechanisms of the folk melody thorugh the use of a modal diatonic language with no enlarged seconds - which the Master 
considered inexhaustible - enriched with a "superiour technique of registry, dispozition and an able movement of the voices or through an infinitude of novel sound situations" (Grigoriu, 1986, p. 407) and though the use of small intervals on the vocal line with expressive valences always embellished by the voice-piano symbiosis.

Although the unfolding speed of the play, situated in the area of rapid movements, is aparently uniform ${ }^{11}$, still the prosody (alternative measures), the subdivision of the reference value, the indications of expression, the caesuras and fermatas on the double bar which delimit sond frescoes offers the discourse, a special influence, a play of dramatic tension unique in the vocalchamber creation signed by Theodor Grigoriu. An unusual aspect is the placement of the tempo note above the vocal score, while the metronomic note is meticulously situated above the instrumental score. As such it's induced the intetion for the voice to narrate and the piano to to comment on the narration either by leghtening the echo of the words in the text or by structuring the thought, the feelig, the attitude of the iconograph towards the characters within the pictures he is restoring wide.

If the vocal dificulty is due to the just and expressive coverage of a generous ambitus $\left(\mathrm{A}-\mathrm{g}^{1}\right)$, the pianistic difficulty is to pull off the superb display of complex technico-expressive arsenal attributed by the composer: subtle combination of the articulation types, ritch rhytmics without the use of exceptional division but the use of prosody to a great effect and the play of exceedingly plastic accents, an array of nuances from fff to $p$.

I found, as is the case with other lieber by the Master, the visual spectacle of the score: the finesse of the brushes in redacting the manuscript, as if "expressing a charm of human sensibilities" (Cosma, 2016, in Marinescu, p. 9), the apparent sobriety of the notations and their efficiency within the interpretative investigation, the lack of ostentation correlated with sounds of great plasticity and, paradoxically, the liberty grated to the interprets in the conditions of the numerous articulation notes, the dynamic and agogic noted scruplously. I would later find, shynthetically expressed - by the composer Dan Dediu - a possible explanation for the seduction exerthed by the Master's writing: "He knew (Th. Grigoriu, o.n.) what resounded and what not as he knew very well how to load with reason each note he laid down on paper. His thoroughness was proved through the way he wrote his compositions, giving them not only an optimal acoustic expression thorugh an ebullient instrumental imagination, but also through an astonishing graphic expression” (Dediu in Marinescu, 2016, p. 73).

In the relationship we can define as contrapuntal between the word and the music, the melodic word becomes a deposit richer and more comprehensive

\footnotetext{
${ }^{11}$ You will see metronomic indication for every structural articulation.
} 
in sense, a summoner of images and ideas. Theodor Grigoriu, consistently following the depth of the word's sense, achieving this thorugh the almost mathematical saving of means and thorugh the contribution of all the elements which configure sounds without generating babylonian demonstrative agglomerations, but rahter though a suple and plastic melodic discourse.

From the research up to this point it resulted that the lied has not yet been presented to the public in the voice-piano formula but only though a solo bassoon variant which could not unravel the whole value of this creation, still waiting for an interpretation that does justice to it's value as a coronat opus of the vocal-chamber creation pertaining to Theodor Grigoriu.

\section{Conclusions}

The vast creation of Theodor Grigoriu, "a Patriarch, a great Wise in the Fortress of Music” (Codrin, 2014 in Marinescu, 2014), is a subject of rare research, the creation of lied, especially his last two lieder being novel topics.

"The view from the semi-distance [...], neither panoramic perspective, nor microscopic view" (Banu, 2017, p. 18) on the last two lieder belonging to Theodor Grigoriu and his vocal-chamber creations, offers a series of elements resulting from significant contextualization and observation. These are especially useful for practitioners, for the realization of an interpreter's strategy (the practical study according to the analysis of the musical-poetic text, the identification of the appropriate means of artistic expression and the crystallization of an own interpretative concept) in which the novelty of the information invested with sensitivity stimulates the fantasy andcreativity.

The voice and piano lieder, scatter over more than seven decades of work by the composer Theodor Grigoriu configure areas of interest (creation laboratories) along with works of broader genres (symphonic, vocalsymphonic, concert, chamber, choral) around which they gravitate, being unified as we have shown.

As I pleaded, I consider that the 44 lieder can be reunited under the name of lied creation: they are representative works for the composer's creation, but also for the Romanian lied of the $20^{\text {th }}$ century; are testament to the spiral trajectory the music and the Master's ideas partook in over the course of time; are faithful expressions of what the lied means in the $20^{\text {th }}$ century - "The same spirit comes forth from two different sources and flows into one configuration, in wich word and tone become one, and the mood harmonizes with all this as a pure consonance" (Hans Pfitzner, "Die neue Ästhetik der musikalischen Impotenz” în Gesammelte Schrifften, vol. II, Augsburg, 1926, p. 212 apud James Parsons, "The Lied in the modern age: to mid century", in: James Parsons (editor), The Cambridge Companion to the Lied, Cambridge University Press, 2004, p. 283). 
The last two lieder completed by Theodor Grigoriu, Scrisoare către păsări... [Letter to birds on words by St. Francisc of Assisi] and Iconarul... [The Iconographer...] are atypical, completely different from what the composer had done before, surprising by creative fantasy, the choice of texts and original aproach. However his unconditional love and permanent preocupation for the sound and word transpire, the two universes always entwined. "The sound and word are floating islands in the infinite ocean of Silence; the thought of one sent over the territory of the other returns enriched, brings with it new colours and valences. Who invented the wings and went further is a controversy: musicians will say that poetry, poets will say music. The neighbouring and "conspiracy» between Sound and Word will forever arouse Idea, the sovereign light that reconciles them” (Grigoriu, 2006, p. 98).

\section{References}

Banu, G. (2017). Cehov, aproapele nostru. Traducere de Vlad Russo [Cehov, our neighbour. Translation by Vlad Russo]. București: Editura Nemira.

Barenboim, D. (2015). O viaţă în slujba muzicii, traducere din engleză de Dana-Ligia Ilin [A life in the service of Music, translation from English by Dana-Ligia Ilin]. Bucureşti: Editura Humanitas.

Bura, C. (2016). Privilegiul de a-l fi cunoscut personal [Privilege to have known him personally]. In Marinescu, M. (superv.), In memoriam Theodor Grigoriu: (1926-2014) (pp. 95-97). București: Editura Muzicală.

Codrin, Ș. (2016). Theodor Grigoriu, sau de la „eşec” la „dincolo de tăcere [Theodor Grigoriu or from "failure" to "beyond silence"]. In: Marinescu, M. (superv.). In memoriam Theodor Grigoriu: (1926-2014) (pp. 85-90). București: Editura Muzicală.

Constantinescu, G. (2013). Nocturn şi diurn în muzicăă [Nocturnal and diurnal in Music], 1. Bucureşti: Editura Muzicală.

Constantinescu, G. (2016). Patru secole de lied [Four centuries of Lied]. Bucureşti: Editura Muzicală.

Cosma, V. (2000). Muzicieni din România. Lexicon biobibliografic, III [Musicians from Romania. A biobibliographical lexicon]. Bucureşti: Editura Muzicală.

Cosma, V. (2016). Gânduri postume la reîntâlnirea cu prietenul dispărut [Posthumous thoughts at reunion with the missing friend]. In Marinescu, M. (superv.), In memoriam Theodor Grigoriu: (1926-2014) (pp. 7-10). București: Editura Muzicală.

Dediu, D. (2016). Acribie și visare [Rigor and dreaming]. In Marinescu, M. (superv.), In memoriam Theodor Grigoriu: (1926-2014) (pp. 72-74). București: Editura Muzicală. 
Grigorescu, O. (2016). O operă ce va dăinui [A work that will last]. In Marinescu, M. (superv.), In memoriam Theodor Grigoriu: (1926-2014) (pp. 91-94). București: Editura Muzicală.

Grigoriu, Th. (1979). Fuziunea cuvânt-muzică [The fusion between Word and Music]. Muzica, 4. București.

Grigoriu, Th. (1986). Muzica şi nimbul poeziei, ediția I [Music and the halo of Poetry, $1^{\text {st }}$ edition]. Bucureşti: Editura Muzicală.

Grigoriu, Th. (1989). Olivier Messiaen la 80 de ani [Olivier Messiaen at the age of 80]. Muzica, 3. Bucureşti.

Grigoriu, Th. (2006). Internet. Consultant, coordinator and author of some texts Mihaela Marinescu-Grigoriu. Paris: Editions Musicales Transatlantiques \& Amsterdam: Larghetto \& Bucureşti: ArSSonora.

Manolache, L. (2002). Şase portrete de compozitori români [Six portraits of Romanian Composers]. Bucureşti: Editura Muzicală.

Marinescu, M. (superv.) (2016). In memoriam Theodor Grigoriu: (1926-2014). București: Editura Muzicală.

Nemescu, O. (1983) Capacităţile semantice ale muzicii [Semantic capacities of Music]. Bucureşti: Editura Muzicală.

Parsons, J. (2004). The Lied in the modern age: to mid century. În: James Parsons (editor), The Cambridge Companion to the Lied (pp.273-297). Cambridge: Cambridge University Press.

Sandu-Dediu, V. (2002). Muzica românească între 1944-2000. Principali colaboratori: Antigona Rădulescu [Romanian Music between 1944-2000. Main collaborators: Antigona Rădulescu]. Bucureşti: Editura Muzicală.

Sandu-Dediu, V. (2004). Muzica nouă între modern şi postmodern [New music between modern and postmodern]. Bucureşti: Editura Muzicală.

Sandu-Dediu, V.\& Dediu-Sandu, D. (2013). Dan Constantinescu: esenţe componistice [Dan Constantinescu - Componistic essences]. Bucureşti: Editura Muzicală.

Codrin, Ș. (2014). S-a stins din viață maestrul Theodor Grigoriu. Obiectiv Ialomița Slobozia. Retrieved from https://obiectiv.net/s-a-stins-din-viata-maestrul-theodorgrigoriu-20440.html/

Constantinescu, G. (2014). Theodor Grigoriu - Maestrul ne-a părăsit [The Master left] [Cronica muzicală on-line/ Musical Chronicle on-line]. Retrieved from http://www.cimec.ro/Muzica/Cronici/GrConstantinescu429.html

Constantinescu, G. (2014). „Viaţa de creaţie”, continuitate în timp a destinului artistului dispărut - compozitorul Theodor Grigoriu [The creation life, continuity in time of the disappeared artist's destiny - Theodor Grigoriu the composer]. Actualitatea muzicală, 5. București. Retrieved from http://www.ucmr.org.ro/texte/am2014-05.pdf 
Vodă, E. (2011). Profesioniștii - Theodor Grigoriu [The Proffesionals - Theodor Grigoriu] taken from http://www.eugeniavoda.ro/ro/emisiuni/arte/theodor-grigoriu

Grigoriu, Th. (2016). Scrisoare către păsări a Sfântului Francisc din Assisi [Letter to the Birds of Saint Franscisc of Assisi]. Bucureşti: Editura Muzicală.

Grigoriu, Th. (2016). Iconarul - Poemul unui zugrav de biserici [The iconographer The poem of a church painter]. Bucureşti: Editura Muzicală. 